\title{
Macroalgae reduce growth of juvenile corals but protect them from parrotfish damage
}

\author{
D. E. Venera-Ponton ${ }^{1,4, *}$, G. Diaz-Pulido ${ }^{2}$, L. J. McCook ${ }^{3}$, A. Rangel-Campo ${ }^{4}$ \\ ${ }^{1}$ Department of Biology, University of Louisiana at Lafayette, PO Box 42451, Lafayette, Louisiana 70504-2451, USA \\ ${ }^{2}$ Griffith School of Environment and Australian Rivers Institute - Coast and Estuaries, and Australian Research Council \\ Centre of Excellence for Coral Reef Studies, Griffith University, Nathan, Brisbane, Queensland 4111, Australia \\ ${ }^{3}$ Great Barrier Reef Marine Park Authority, Australian Research Council Centre of Excellence for Coral Reef Studies and \\ Pew Fellowships Program in Marine Conservation, PO Box 1379, Townsville, Queensland 4810, Australia \\ ${ }^{4}$ Instituto de Investigaciones Tropicales, Universidad del Magdalena, Carrera 32 \# 22-08, Santa Marta, Colombia
}

\begin{abstract}
Inhibition of early life stages of corals by benthic algae is a critical bottleneck to the recovery and resilience of corals. Increasingly frequent and severe disturbances are causing largescale coral mortality, usually followed by colonisation and dominance by benthic algae. The capacity of corals to re-establish in such algal-dominated habitats will depend on the effects of the algae on growth and survivorship of juvenile corals. We experimentally evaluated the competition between juvenile corals Porites astreoides and algae and the effects of algae on the exposure of juvenile corals to damage by parrotfishes (family Scaridae) in a Colombian Caribbean reef. We also explored whether those effects were consistent among climatic seasons (upwelling and non-upwelling). Benthic algae had negative and positive effects on the juvenile corals. The removal of algal turfs and fleshy macroalgae enhanced coral growth. Unexpectedly, removal of algae from around the juvenile corals increased predation upon the corals by parrotfishes. When algae were removed, at least $50 \%$ of the corals were grazed by parrotfishes, but no bites were observed on corals with intact algae. Coral growth and parrotfish damage were not affected by season. However, damage by parrotfishes neither lessened survivorship nor resulted in negative growth for any of the grazed coral colonies. The beneficial effects of algae in protecting the juvenile corals from parrotfish damage seem to be outweighed by the negative effects of the algae on coral-algal competition. Understanding such complexities in the interactions between algae and early life stages of corals can provide insight into the roles of algae in coral reef resilience.
\end{abstract}

KEY WORDS: Coral-algal competition - Parrotfish predation · Juvenile corals · Upwelling reef • Coral growth $\cdot$ Porites astreoides

\section{INTRODUCTION}

Many coral reefs around the world have experienced declines in coral abundance and increases in benthic algae as a consequence of local and global stressors (Hughes 1994, Ostrander et al. 2000, Bellwood et al. 2004). Successful recovery of coral populations largely depends on the ability of coral larvae to settle and recruit on substrata dominated by benthic algae (McCook et al. 2001, Birrell et al. 2008). Therefore, competition between corals and algae is a pivotal process in coral-to-algal phase shifts, reef resilience and the ecology of reefs in general. Benthic algae compete with corals by using a variety of mechanisms, such as overgrowth, smothering, shading, abrasion, allelochemical interactions, and by promoting bacterial growth on the corals causing mortality, especially in juvenile corals (McCook et al. 2001, Nugues et al. 2004, Smith et al. 2006, Box \& Mumby 2007, Rasher \& Hay 2010). Importantly, algae may pre-empt space, 
inhibiting coral settlement and creating adverse microenvironments. This reduces survival of established coral recruits and juveniles resulting in profound consequences for coral populations (Miller \& Hay 1996, Hughes et al. 2007, Mumby et al. 2007, Birrell et al. 2008).

Early life stages of corals are more susceptible to competitive suppression and whole-colony mortality, probably because young corals have fewer energy reserves to invest in competition than do adult corals (Raymundo \& Maypa 2004, Box \& Mumby 2007, Birrell et al. 2008). Algae that have minor effects on the performance of adult corals may have important negative effects on coral settlement and early recruitment (Kuffner \& Paul 2004, Birrell et al. 2005, Kuffner et al. 2006, Box \& Mumby 2007). Some studies have also demonstrated that many algal species may be competitively inferior to adult corals (McCook 2001, DiazPulido et al. 2009). However, few studies have experimentally addressed the effects of benthic algae on juvenile corals, or the roles of climatic variability and associated algal seasonality in driving juvenile coralalgal interactions (Birrell et al. 2008), particularly in reefs influenced by seasonal upwelling. Upwelling reefs experience dramatic fluctuations in algal assemblage composition (Diaz-Pulido \& Garzón-Ferreira 2002), and it is likely that competitive interactions between algae and corals also change seasonally.

In the present study, we experimentally evaluated the competitive effects of benthic algae on the growth and survival of juveniles of the coral Porites astreoides and the effects of algae on the susceptibility of juvenile corals to predation in the Tayrona National Natural Park (TNNP), Colombia, in the southern Caribbean Sea. Coastal habitats in the TNNP experience seasonal upwelling and are exposed to alternating periods of low and high water temperature. To explore whether climatic seasons and resulting algal composition affect the competitive interactions, we conducted the study during the upwelling and non-upwelling (rainy) season. Since it has been suggested that the presence of fleshy macroalgae (e.g. Dictyota pulchella, Lobophora variegata) may increase the exposure of juvenile corals to accidental whole-colony predation by grazing parrotfishes (family Scaridae) (Box \& Mumby 2007), we explored whether these types of effects also occurred in our study site.

\section{MATERIALS AND METHODS}

Study site: oceanography and algal assemblages. The study was conducted on a rocky reef in Granate Bay, TNNP, in the Colombian Caribbean Sea. The hard bottom in the bay is mostly granitic rocks and is generally covered by abundant algal turfs and fleshy seaweeds, with relatively low coral cover $(<20 \%$, authors' unpubl. data), but Diploria spp., Siderastrea siderea, Porites astreoides and Millepora spp. corals are common. Juvenile $P$. astreoides corals are common on the upper parts of the granitic rocks (between 3 and $5 \mathrm{~m}$ depth) and are usually surrounded by algal turfs with an understory of coralline algae and by seasonal beds of Sargassum spp. (see below).

Marine communities in the area are influenced by a main seasonal upwelling during December to April, with a minor upwelling period from July to August. Upwelling waters have low temperature (generally 24.1 to $26.4^{\circ} \mathrm{C}$, but may drop to as low as $21^{\circ} \mathrm{C}$ ), high salinity (36.1 to 37.4 ) and clarity, and moderate inorganic nutrients. There is a main non-upwelling (rainy) season from September to November and a minor rainy period from May to June. The non-upwelling period is characterised by increased rain, runoff and water temperature $\left(27.4\right.$ to $28.6^{\circ} \mathrm{C}$ ) (Bula-Meyer 1985, Garzón-Ferreira 1998).

The abundance and composition of the algal assemblages in the TNNP vary seasonally in response to temperature (Diaz-Pulido \& Garzón-Ferreira 2002). Algal turfs dominate the study site during the nonupwelling season and include predominantly filamentous forms, such as Anotrichium spp., Bryopsis spp., Ceramium spp., Gelidiella spp., Gelidiopsis spp., Herposiphonia spp., Polysiphonia spp., Sphacelaria spp., Ulva spp. and cyanobacteria. Some calcareous algae, such as Jania spp. and Amphiroa spp., and early stages of fleshy macroalgae, such as Dictyota spp., Laurencia spp. and Hypnea spp., are usually found within the turfs. In contrast, Sargassum spp. dominate the study site during the upwelling and other fleshy macroalgae (Dictyota spp., Lobophora variegata, Laurencia spp., Padina spp.) are present as understory. Interactions between corals and benthic algae also vary with seasons and the frequency of interactions is related to the abundance of algae (Mejía-Niño \& Garzón-Ferreira 2003).

Experimental design. To explore the competitive effects of benthic algae on the growth of juvenile corals Porites astreoides and test whether the climatic variability (and the resulting shift in algal assemblage composition) affects coral-algal competition, we conducted an algal removal experiment during 2 climatic seasons: main non-upwelling season (October to December 2006, 74 d) and upwelling season (January to April 2007, 63 d). We used 3 coral-algal competition treatments: (1) juvenile corals with the surrounding algae removed, (2) juvenile corals with intact algae (natural control) and (3) partial removal of coral tissue. These treatments were intended to test whether there 
is competition for space between algae and juvenile corals; if the interaction is indeed competitive, the colonization ability of each organism must be improved by the removal/damage of the other (see Underwood 1986, McArdle 1996, McCook et al. 2001). In the algal removal treatment, both algal turfs and fleshy macroalgae were removed from a $10 \mathrm{~cm}$ area around the juvenile corals by using a wire scouring pad and a nail tip (used on a $1 \mathrm{~cm}$ area around the coral to avoid coral tissue damage) and manually pulling off larger algae (particularly when Sargassum spp. were present). In each of the 2 main climatic seasons algal removal was repeated fortnightly, starting at the beginning of the experiment for a period of ca. $10 \mathrm{wk}$. For the coral damage treatment, the coral tissue was removed in a band $6 \mathrm{~mm}$ wide and 3 to $4 \mathrm{~mm}$ deep around the perimeter of the coral by gently rubbing a screw along the band. Sixty juvenile corals were randomly assigned to each of the 3 treatments (10 corals per treatment per season). We chose healthy and undamaged coral colonies with a maximum diameter of $<2.5 \mathrm{~cm}$ because corals at this size are still immature (maturity size for P. astreoides is ca. $8 \mathrm{~cm}$ diameter, Soong 1993). Each juvenile coral was marked for future relocation.

Response variables and data analysis. Response variables included growth and parrotfish damage of juvenile corals. Growth was estimated by measuring the change in maximum diameter of healthy tissue with a calliper for each coral in each season (Fig. 1). The change in perimeter and surface length were also estimated during the upwelling, using a cord placed along the coral-algal boundary (perimeter) and over the coral surface along the maximum coral diameter (surface length), respectively (Fig. 1). Because coral perimeter and surface length change were signifi- cantly correlated with diameter change (Pearson correlation; all $\mathrm{p}<0.05, \mathrm{r}^{2}>40 \%$ ) and showed the same outcome, their results are not shown. Change in diameter, surface length and perimeter indicate how much substrate has been gained by each organism at the expense of the other: positive values indicate corals overgrew the surrounding algae, while negative values indicate algae overgrew corals.

Studies on coral-algal competition usually employ photographic techniques (e.g. McCook 2001, Nugues \& Bak 2006, Box \& Mumby 2007), which can accurately estimate the coral growth. By contrast, our study used simple variables (diameter, perimeter and surface length), which are less precise but sensitive enough to detect significant differences between treatments (see Table 1).

To test whether algae affect the exposure of juvenile corals to parrotfish damage, we counted the number of corals grazed by parrotfishes in each treatment at each season. Parrotfishes were actively seen grazing on corals and the resulting scars are easily recognisable in the field (Bruckner et al. 2000, Rotjan \& Lewis 2005). Scars were registered fortnightly.

Change in coral diameter was compared between treatments and seasons with a factorial ANOVA and a Tukey's post hoc test. Homoscedasticity and normality of residuals were tested using Cochran's and ShapiroWilks' tests, respectively. The frequency of colonies with and without bites was compared between the 'algal removal' and 'control' treatments and seasons using Fisher's tests. Finally, because a standard amount of tissue was damaged in corals of variable size, simple regression models were tested for coral growth versus percent area damaged in the coral damage treatment.
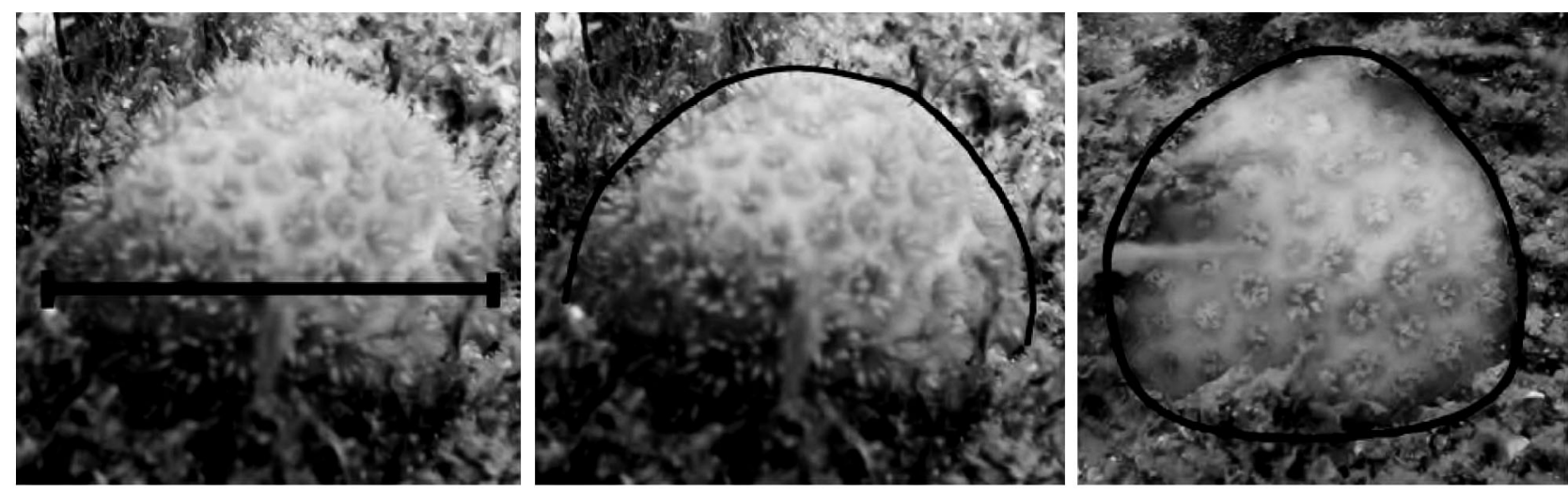

Fig. 1. Porites astreoides. Coral variables measured. We used the change in maximum diameter (left panel), surface length (centre panel) and perimeter (right panel) as response variables to evaluate the coral-algal competition in the experiment. The length of the black lines represents each response variable. Positive changes indicated coral overgrew algae, while negative changes indicated algae overgrew corals 


\section{RESULTS}

The presence of algae around the juvenile corals reduced coral growth. The change in coral diameter (Fig. 2, Table 1), perimeter and surface length were 66, 43 and $49 \%$ lower, respectively, when algae were present (control treatment) than when algae were removed. The damaged coral tissue was frequently overgrown by filamentous turfing algae, demonstrating that competitive effects were mutual with healthy coral inhibiting algal growth. Climatic season did not significantly affect coral-algal competition or the growth of the juvenile corals (Table 1). However, algal overgrowth (mainly algal turfs) of damaged corals, indicated by negative values of coral growth, mainly occurred during the upwelling season (Fig. 2). Regression models found poor correlation between percent area damaged and diametric growth (model $\mathrm{p}>0.05$, $\mathrm{r}^{2}<5 \%$; best model: reciprocal- $x$ ).

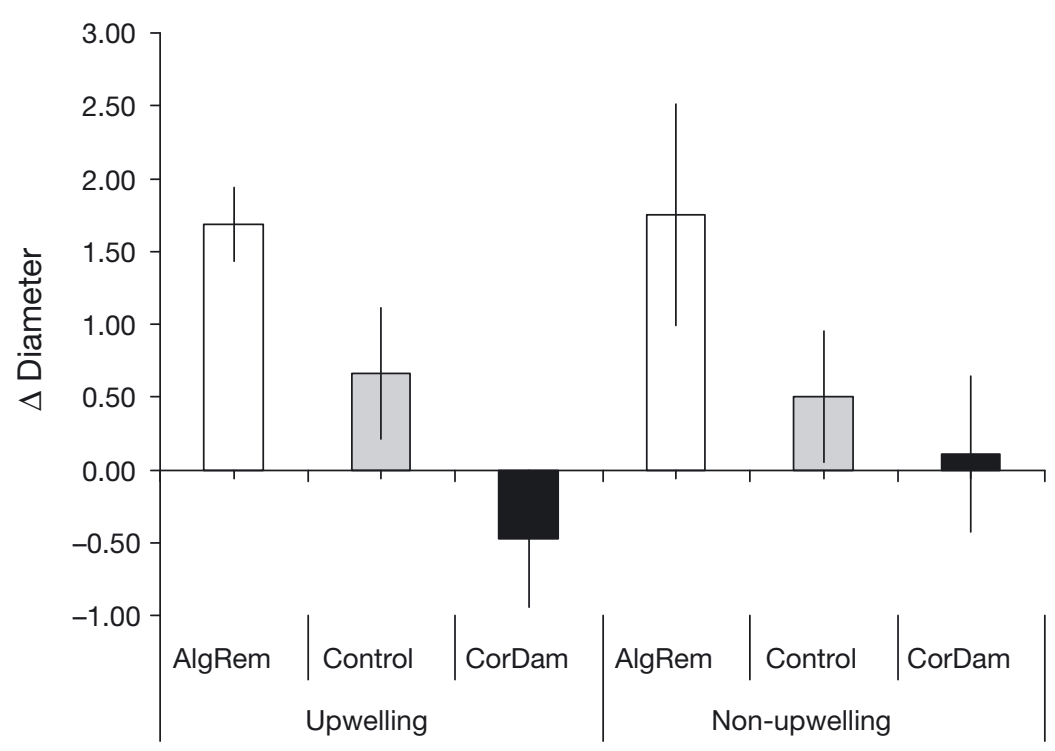

Fig. 2. Porites astreoides. Average change (mean $\pm \mathrm{SE}$ ) of maximum coral diameter $(\mathrm{mm})$ across algal treatments and climatic seasons. Coral perimeter and surface length showed the same pattern as maximum diameter during the upwelling season (data not shown). AlgRem: algal removal; CorDam: coral damage. $\mathrm{N}=60$ ( $\mathrm{n}=10$ replicates per treatment per season)

Table 1. Porites astreoides. Results of the ANOVA for change in maximum coral diameter. Because the factor Season was nonsignificant for change in maximum diameter, seasons were pooled in a subsequent 1-way ANOVA. Tukey's test results for this ANOVA are presented. An asterisk $\left({ }^{*}\right)$ represents a p-value $=$ 0.06. A: algal removal; $\mathrm{N}$ : natural control; D: coral damage

\begin{tabular}{|lrrccc|}
\hline $\begin{array}{l}\text { Source of } \\
\text { variation }\end{array}$ & df & MS & $F$ & $p$ & $\begin{array}{l}\text { Conclusion } \\
\text { (Tukey's test) }\end{array}$ \\
\hline Competition (C) & 2 & 17.339 & 6.794 & 0.002 & A > N* $, \mathrm{N}=\mathrm{D}, \mathrm{A}>\mathrm{D}$ \\
Season (S) & 1 & 0.386 & 0.151 & 0.699 & \\
$\mathrm{C} \times \mathrm{S}$ & 2 & 0.683 & 0.267 & 0.766 & \\
Error & 52 & 2.552 & & & \\
\hline
\end{tabular}

\section{DISCUSSION}

Competition between corals and benthic algae in coral reefs is a critical ecological process driving the dynamics of both the algae and the corals (Mumby et al. 2007, Birrell et al. 2008). Although there is increasing information on the competitive effects of algae on adult corals (see McCook et al. 2001), little is known about these effects on early life stages of corals (Kuffner et al. 2006, Birrell et al. 2008, Vermeij et al. 2009, Diaz-Pulido et al. 2010), particularly the earliest stages (Birrell et al. 2008). In this study we showed that the same benthic algae can have both negative and positive effects on juvenile Porites corals. The presence of both algal turfs and fleshy macroalgae reduced the growth of the corals, but surprisingly, the removal of the algae from around the corals increased predation upon the juvenile corals. This demonstrates that the interactions between algae and early life stages of corals are complex, with potential implications for understanding the roles of algae in coral reef resilience.

Importantly, the negative effects of benthic algae on the juvenile corals did not vary among the 2 main climatic seasons, despite large variability in the type of algal communities occurring in the upwelling and rainy (nonupwelling) seasons. Large stands of fleshy seaweeds such as Sargassum 
spp. dominated the upwelling season, while thin filamentous algal turfs were common during the rainy period. The nature and composition of the algal community may have variable effects on coral population dynamics (Birrell et al. 2008, Diaz-Pulido et al. 2010, Rasher \& Hay 2010). For example, algal turfs may have minor competitive effects on adult corals (Meesters et al. 1997, McCook 2001, Jompa \& McCook 2003) compared with thick algal mats or fleshy macroalgae, which can reduce light or abrade coral tissue (Miller \& Hay 1996, Nugues et al. 2004, Smith et al. 2006). In our study, both types of algal communities (algal turfs and fleshy seaweeds) reduced the growth of juvenile corals (Fig. 2) potentially by mechanisms such as allelopathy or sediment trapping in the case of turfs, or by shading, abrasion, allelopathy, sediment trapping and oxygen depletion in the case of fleshy seaweeds (McCook et al. 2001, Birrell et al. 2008, Rasher \& Hay 2010). As growth of juvenile corals was reduced by algal turfs that usually do not affect adult corals (see Meesters et al. 1997, McCook 2001, Jompa \& McCook 2003), our results support the idea that early life stages of corals are more susceptible to competitive suppression by benthic algae than are adult corals (see Birrell et al. 2005, Box \& Mumby 2007).

However, the presence of algae around the juvenile corals may to some extent also benefit coral populations by reducing the risk of predation by parrotfishes. In this experiment, juvenile corals with surrounding algae present were not grazed, whereas at least $50 \%$ of juvenile corals with algal turfs and fleshy seaweeds removed were grazed by parrotfishes. This suggests that benthic algae may provide protection for the corals from parrotfish grazing, potentially enhancing coral survivorship. These results are in contrast with those of Box \& Mumby (2007) who inferred that the presence of fleshy seaweeds indirectly increases exposure of coral recruits to whole-colony predation by grazing parrotfishes. Bak \& Engel (1979) also suggested that parrotfish bites were an important source of injuries in coral recruits and juveniles, but did not explore the relationship with algae. Yet the damage caused by parrotfishes neither lessened survivorship nor resulted in negative growth for any of the grazed colonies. Thus, the positive effects of the algae in reducing corallivory on the juvenile corals appear to be outweighed by the negative effects of the algae on coral growth and condition. However, the long-term consequences of the corallivory for coral population dynamics, and the role of benthic algae in mediating this interaction, are unknown and warrant further research (see also Mumby 2009).

The protection against parrotfish predation provided by algae on corals may be explained by 2 mechanisms: (1) algae camouflage corals from the view of parrot- fishes and (2) associational defences. The latter mechanism has been widely documented in marine (Hay 1986, Wahl \& Hay 1995) and terrestrial (Atsatt \& O'Down 1976) ecosystems and refers to the protection gained from the association with low-palatability species, which create microhabitats of lowered grazing. The fleshy macroalgal assemblages of the study site are dominated by Sargassum spp., which is of low palatability (Hay 1986, Wahl \& Hay 1995, Ceccarelli et al. 2005) and may provide associational defences for juvenile corals against parrotfish predation. By contrast, the algal turf assemblage includes both palatable (e.g. Polysiphonia spp., Ulva spp.; Hay 1986, Wahl \& Hay 1995) and unpalatable species (e.g. Jania spp., Amphiroa spp.; Cruz-Rivera \& Villareal 2006). It is possible that unpalatable turf-forming species provided associational defences not only for palatable turf species, but also for juvenile corals. This defence, however, may turn into a shared doom (prejudice gained from the association with highly palatable species; Hay 1986, Wahl \& Hay 1995) in reefs dominated by high palatable algae. Nevertheless, this warrants further research.

The long-term consequences of the algal suppression on juvenile corals also warrant further research. It is possible, for instance, that the long-term consequences of algal suppression on juvenile corals are even more complex than predicted by this short-term study. This, however, is a common dilemma of experimental studies due to the high costs and complexities of controlling factors during the long term (see McCook et al. 2001). Corals with intact algae experienced growth rates similar to that observed for Porites astreoides in the Caribbean Sea (see Huston 1985, Chornesky \& Peters 1987, Logan \& Tomascik 1991). By contrast, corals with algae removed surpassed this rate more than twofold. This high growth rate might be caused, in part, by tissue regeneration without polyp formation on the coral lesions. However, once the colonies are fully recovered, the long-term growth may slow down.

Many coral reefs have experienced large-scale degradation and ecological phase shifts from coral to algal dominance (e.g. Atlantic Ocean: Hughes 1994, Ostrander et al. 2000; Indian Ocean: McClanahan et al. 2001). This study provides insight into the ecological resilience of coral populations, particularly under climate change scenarios that suggest increases in coral mortality and algal overgrowth (Hoegh-Guldberg et al. 2007, Diaz-Pulido et al. 2009). Recovery from disturbances by means of sexual reproduction may occur more slowly on reefs with abundant thick algal turfs and fleshy seaweeds than those with fewer algae. Reduced coral growth increases size-dependent vulnerability of juvenile corals (and consequent whole- 
colony mortality), since the corals take longer to reach a refuge size from competitive suppression by benthic algae (Raymundo \& Maypa 2004, Box \& Mumby 2007). Understanding the complexities involved in the direct and indirect effects of algae on coral recruitment and survival will contribute to the understanding of the variability in coral population recovery and reef resilience.

Acknowledgements. We thank the Colombian Institute for Advancement of Science and Technology (COLCIENCIAS), the Pew Fellowships Program in Marine Conservation and the Instituto de Investigaciones Tropicales of the Universidad del Magdalena, Colombia, for support. Thanks to R. Londoño, O. Camacho, L. Florez-Leiva, M. Salcedo, A. Lopez and B. Zúniga for help in the field and D. Bender for discussions.

\section{LITERATURE CITED}

Atsatt PR, O'Down DJ (1976) Plant defense guilds. Science 193:24-29

Bak RPM, Engel MS (1979) Distribution, abundance and survival of juvenile hermatypic corals (Scleractinia) and the importance of life history strategies in the parent coral community. Mar Biol 54:341-352

Bellwood DR, Hughes TP, Folke C, Nystrom M (2004) Confronting the coral reef crisis. Nature 429:827-833

> Birrell CL, McCook LJ, Willis BL (2005) Effects of algal turfs and sediment on coral settlement. Mar Pollut Bull 51: 408-414

Birrell CL, McCook LJ, Willis BL, Diaz-Pulido GA (2008) Effects of benthic algae on the replenishment of corals and the implications for the resilience of coral reefs. Oceanogr Mar Biol Annu Rev 46:25-64

$>$ Box SJ, Mumby PJ (2007) Effect of macroalgal competition on growth and survival of juvenile Caribbean corals. Mar Ecol Prog Ser 342:139-149

Bruckner AW, Bruckner RJ, Sollins P (2000) Parrotfish predation on live coral: 'spot biting' and 'focused biting'. Coral Reefs 19:50

Bula-Meyer G (1985) Un núcleo nuevo de surgencia en el Caribe colombiano detectado en correlación con las macroalgas. Bol Ecotrópica 12:2-26

> Ceccarelli DM, Jones GP, McCook LJ (2005) Effects of territorial damselfish on an algal-dominated coastal coral reef. Coral Reefs 24:606-620

Chornesky EA, Peters EC (1987) Sexual reproduction and colony growth in the scleractinian coral Porites astreoides. Biol Bull (Woods Hole) 172:161-177

> Cruz-Rivera E, Villareal TA (2006) Macroalgal palatability and the flux of ciguatera toxins through marine food webs. Harmful Algae 5:497-525

> Diaz-Pulido G, Garzón-Ferreira J (2002) Seasonality in algal assemblages on upwelling-influenced coral reefs in the Colombian Caribbean. Bot Mar 45:284-292

Diaz-Pulido G, McCook L, Dove S, Berkelmans R and others (2009) Doom and boom on a resilient reef: climate change, algal overgrowth and coral recovery. PLoS ONE 4:e5239

Diaz-Pulido G, Harii S, McCook LJ, Hoegh-Guldberg O (2010) The impact of benthic algae on the settlement of a reef-building coral. Coral Reefs 29:203-208

Garzón-Ferreira J (1998) Bahía de Chengue, Parque Natural Tayrona, Colombia. In: Kjerfve B (ed) CARICOMPCaribbean coral reef, seagrass and mangrove sites. UNESCO, Paris, p 115-125
Hay ME (1986) Associational plant defenses and the maintenance of species diversity: turning competitors into accomplices. Am Nat 128:617-641

Hoegh-Guldberg O, Mumby PJ, Hooten AJ, Steneck RS and others (2007) Coral reefs under rapid climate change and ocean acidification. Science 318:1737-1742

Hughes TP (1994) Catastrophes, phase shifts, and large-scale degradation of a Caribbean coral reef. Science 265: $1547-1551$

Hughes TP, Rodrigues MJ, Bellwood DR, Ceccarelli D and others (2007) Phase shifts, herbivory, and the resilience of coral reefs to climate change. Curr Biol 17:360-365

Huston M (1985) Variation in coral growth rates with depth at Discovery Bay, Jamaica. Coral Reefs 4:19-25

Jompa J, McCook LJ (2003) Contrasting effects of turf algae on corals: massive Porites spp. are unaffected by mixedspecies turfs, but killed by the red alga Anotrichium tenue. Mar Ecol Prog Ser 258:79-86

Kuffner IB, Paul VJ (2004) Effects of the benthic cyanobacterium Lyngbya majuscula on larval recruitment of the reef corals Acropora surculosa and Pocillopora damicornis. Coral Reefs 23:455-458

Kuffner IB, Walters LJ, Becerro MA, Paul VJ, Ritson-Williams $\mathrm{R}$, Beach KS (2006) Inhibition of coral recruitment by macroalgae and cyanobacteria. Mar Ecol Prog Ser 323: $107-117$

> Logan A, Tomascik T (1991) Extension growth rates in two coral species from high-latitude reefs of Bermuda. Coral Reefs 10:155-160

McArdle BH (1996) Levels of evidence in studies on competition, predation and disease. NZ J Ecol 20:7-15

McClanahan TR, Muthiga NA, Mangi S (2001) Coral and algal changes after the 1998 coral bleaching: interaction with reef management and herbivores on Kenyan reefs. Coral Reefs 19:380-391

McCook LJ (2001) Competition between corals and algal turfs along a gradient of terrestrial influence in the nearshore central Great Barrier Reef. Coral Reefs 19:419-425

> McCook LJ, Jompa J, Diaz-Pulido G (2001) Competition between corals and algae on coral reefs: a review of evidence and mechanisms. Coral Reefs 19:400-417

Meesters EH, Pauchli W, Bak RPM (1997) Predicting regeneration of physical damage on a reef-building coral by regeneration capacity and lesion shape. Mar Ecol Prog Ser 146:91-99

Mejía-Niño N, Garzón-Ferreira J (2003) Dinámica de las interacciones alga-coral en dos bahías de la región de Santa Marta (Caribe colombiano) con distinto grado de influencia antropogénica. Bol Invest Mar Cost 32:243-261

Miller MW, Hay ME (1996) Coral-seaweed-grazer-nutrient interactions on temperate reefs. Ecol Monogr 66:323-344

Mumby PJ (2009) Herbivory versus corallivory: Are parrotfish good or bad for Caribbean coral reefs? Coral Reefs 28:683-690

> Mumby PJ, Harborne AR, Williams J, Kappel CV and others (2007) Trophic cascade facilitates coral recruitment in a marine reserve. Proc Natl Acad Sci USA 104:8362-8367

Nugues MM, Bak RPM (2006) Differential competitive abilities between Caribbean coral species and a brown alga: a year of experiments and a long-term perspective. Mar Ecol Prog Ser 315:75-86

- Nugues MM, Smith GW, van Hooidonk RJ, Seabra MI, Bak RPM (2004) Algal contact as a trigger for coral disease. Ecol Lett 7:919-923

Ostrander GK, Armstrong KM, Knobbe ET, Gerace D, Scully EP (2000) Rapid transition in the structure of a coral reef community: the effects of coral bleaching and physical dis- 
turbance. Proc Natl Acad Sci USA 97:5297-5302

Rasher DB, Hay ME (2010) Chemically rich seaweeds poison corals when not controlled by herbivores. Proc Natl Acad Sci USA 107:9683-9688

Raymundo LJ, Maypa AP (2004) Getting bigger faster: mediation of size-specific mortality via fusion in juvenile coral transplants. Ecol Appl 14:281-295

Rotjan RD, Lewis SM (2005) Selective predation by parrotfishes on the reef coral Porites astreoides. Mar Ecol Prog Ser 305:193-201

Smith J, Shaw M, Edwards RA, Obura D and others (2006) Indirect effects of algae on coral: algae-mediated, microbe-induced coral mortality. Ecol Lett 9:835-845

Editorial responsibility: Charles Birkeland,

Honolulu, Hawaii, USA
Soong K (1993) Colony size as a species character in massive reef corals. Coral Reefs 12:77-83

Underwood AJ (1986) The analysis of competition by field experiments. In: Kikkawa J, Anderson DJ (eds) Community ecology: pattern and process. Blackwell, Oxford, p 240-268

Vermeij MJA, Smith JE, Smith CM, Vega Thurber R, Sandin SA (2009) Survival and settlement success of coral planulae: independent and synergistic effects of macroalgae and microbes. Oecologia 159:325-336

Wahl M, Hay ME (1995) Associational resistance and shared doom: effects of epibiosis on herbivory. Oecologia 102: $329-340$

Submitted: June 2, 2010; Accepted: October 8, 2010 Proofs received from author(s): December 11, 2010 